\title{
Komposisi jenis kelamin anak, program Keluarga Berencana dan fertilitas
}

\section{Sex composition of children, Family Planning program and fertility}

\author{
Mugia Bayu Rahardja*, Robani Catursaptani, Rahmadewi \\ Pusat Penelitian dan Pengembangan Kependudukan, BKKBN \\ *Korespondensi penulis: raharja82@gmail.com
}

\begin{abstract}
The number and sex composition of children are important for some married couples in Indonesia. Having sons in the family is considered as a must since they are argued to be the successor of the family lineage. The presence of daughters is expected to help with household chores and care for their elderly parents. The sex preference for children by the married couples can affect their number of children. This study aims to assess the relationship between the number and sex composition of children, contraceptive use, and the desire to have more children among women in Indonesia. The study employed the data from the 2017 Indonesian Demography and Health Survey (IDHS), with the unit of analysis of currently married women aged 15-49 who have at least one living children. The results show that women with two or more children of the same sex had a higher tendency to have additional children and no use of contraceptives. The Family Planning program's campaign of similar values shared between son and daughter is still hardly accepted, hence, sex preference still exists. It is necessary to reformulate an effective concept for proper socialization of these values as an effort to control the fertility rate in Indonesia.
\end{abstract}

Keywords: child sex preference, child sex composition, contraception, fertility, family planning

\section{ABSTRAK}

Jumlah dan komposisi jenis kelamin anak adalah hal penting bagi sebagian pasangan suami istri di Indonesia. Memiliki anak laki-laki umumnya dianggap sebagai suatu keharusan karena mereka dipandang sebagai penerus garis keturunan keluarga. Sementara itu, keberadaan anak perempuan diharapkan dapat membantu pekerjaan rumah tangga dan merawat orang tua ketika sudah lanjut usia. Adanya preferensi pasangan suami istri terhadap jenis kelamin anak tertentu dapat berdampak pada jumlah anak dalam keluarga. Kajian ini bertujuan untuk mempelajari hubungan antara jumlah dan komposisi jenis kelamin anak, pemakaian kontrasepsi, serta keinginan memiliki anak lagi pada wanita di Indonesia. Penelitian ini menggunakan data hasil Survei Demografi dan Kesehatan Indonesia (SDKI) 2017 dengan unit analisis wanita kawin umur antara 15-49 tahun yang telah memiliki satu anak masih hidup atau lebih. Hasil penelitian menunjukkan bahwa wanita dengan dua anak atau lebih dan jenis kelaminnya sama memiliki kecenderungan lebih tinggi untuk menambah anak dan tidak menggunakan alat kontrasepsi. Bagian dari program Keluarga Berencana yang mengkampanyekan '(anak) laki-laki dan perempuan sama saja' masih belum dapat diterima oleh sebagian pasangan usai subur sehingga preferensi jenis kelamin anak tertentu masih terlihat. Oleh karena itu, perlu direkayasa kembali konsep yang efektif untuk sosialisasi yang tepat sebagai upaya mengontrol tingkat fertilitas di Indonesia.

Kata kunci: preferensi jenis kelamin anak, komposisi jenis kelamin anak, kontrasepsi, fertilitas, Keluarga Berencana

\section{PENDAHULUAN}

Pasangan suami istri memiliki kecenderungan menyukai anak-anak dengan jenis kelamin tertentu atau memiliki jumlah anak yang sama dari kedua jenis kelamin. Adanya preferensi orang tua terhadap jenis kelamin anaknya secara alamiah akan berdampak pada tingkat fertilitas.
Hal tersebut menjadi penting untuk dipahami sebagai salah satu upaya perbaikan serta kemajuan program kependudukan dan keluarga berencana (KB) di Indonesia.

Jumlah anak yang diinginkan oleh pasangan suami istri merupakan salah satu faktor penting yang memengaruhi perilaku pemakaian kontra- 
sepsi (Hastono, 2009). Hal tersebut sangat dipengaruhi oleh persepsi mereka terhadap nilai anak, baik anak laki-laki maupun perempuan. Keinginan untuk memiliki anak sebagian ditentukan oleh karakteristik latar belakang individu seperti agama, pendidikan, tempat tinggal, tipe dan keluarga. Setiap keluarga mempunyai normanorma dan sikap fertilitas yang dilatarbelakangi oleh karakteristik tersebut (Easterlin, 1983).

Hasil penelitian di beberapa negara berkembang menunjukkan hubungan positif antara nilai anak dan jumlah anak yang diinginkan. Ketika orang tua memiliki persepsi bahwa biaya memiliki anak lebih besar maka orang tua menginginkan jumlah anak yang lebih sedikit. Sebaliknya, ketika anak dipersepsikan memiliki manfaat besar, orang tua cenderung menginginkan jumlah anak yang lebih banyak dalam keluarga mereka (Bulatao \& Lee, 1983).

Preferensi jenis kelamin anak berhubungan dengan peran anak dalam keluarga berdasarkan jenis kelamin. Dalam keluarga, peran anak lakilaki dan anak perempuan berbeda (Mahadevan \& Reddy, 1986). Apabila suatu keluarga hanya memiliki anak dengan satu jenis kelamin tertentu, maka upaya untuk membentuk keluarga kecil mengalami kendala. Orang tua yang hanya memiliki anak perempuan akan terus berupaya untuk mendapatkan anak laki-laki, dan sebaliknya. Hal ini memungkinkan terciptanya keluarga besar dengan jumlah anak yang banyak (Wirawan, 2007). Lebih lanjut, keinginan orang tua memiliki anak laki-laki dan perempuan dalam keluarga akan meningkatkan fertilitas, walaupun hanya berdampak kecil pada tingkat kebahagiaan (Margolis \& Myrskyla, 2016). Pasangan suami istri cenderung menginginkan kedua jenis kelamin anak hadir dalam keluarga mereka walaupun anak laki-laki kadang dianggap memiliki nilai lebih tinggi sebagai imam dalam ibadah dan ahli waris bagi saudara perempuannya (Nurjono, 2014). Hal ini menyebabkan satu keluarga dapat memiliki lebih dari tiga atau empat anak.

Pada beberapa negara di Asia Selatan, anak laki-laki lebih berharga dibandingkan dengan anak perempuan karena alasan ekonomi dan sosial. Mereka juga umumnya dipandang sebagai pendukung dan penerus nama keluarga. Anak laki-laki dianggap akan lebih bisa membawa kesejahteraan di dalam keluarga (Jayaraman dkk., 2009). Preferensi terhadap anak laki-laki merupakan cara orang tua untuk mengikuti norma sosial masyarakat. Namun, banyak pula orang tua yang menginginkan untuk memiliki setidaknya satu anak perempuan (Arnold, 2001). Pada tahun 2000-an, anak perempuan di Swedia lebih diinginkan dibanding anak laki-laki untuk merawat orang tua yang lanjut usia(Johansson dkk., 2003).

Anak laki-laki maupun perempuan diinginkan karena berbagai alasan dan preferensi orang tua yang dibentuk oleh kepentingan dan motif sosial tertentu. Secara umum, anak laki-laki terutama diinginkan untuk kelangsungan garis keturunan dan kebutuhan orang tua akan bantuan praktis serta masalah ekonomi. Sementara itu, anak perempuan diinginkan dalam keluarga untuk membantu pekerjaan rumah tangga dan untuk menemani serta merawat orang tua (Fuse, 2013; Sandström \& Vikström, 2015). Anak laki-laki seringkali dianggap sebagai penerus reputasi keluarga dan anak perempuan sebagai pendamping orang tua saat berusia lanjut (Abassi dkk., 2018). Pada beberapa negara maju di Eropa, tidak ada preferensi jenis kelamin anak tertentu untuk anak pertama dalam keluarga. Namun, preferensi untuk memiliki jenis kelamin anak yang berbeda untuk kelahiran anak berikutnya sangat tinggi. Walaupun pengaruhnya lemah, keluarga dengan dua anak berjenis kelamin sama memiliki dampak pada tingkat kebahagiaan dalam keluarga (Margolis \& Myrskyla, 2016).

Kebijakan KB pada sebagian negara belum mampu secara eksplisit mengurangi preferensi terhadap jenis kelamin anak tertentu. Vietnam dinilai sebagai negara yang berhasil dalam melaksanakan program kependudukan. Namun, program KB yang dilaksanakan secara masif belum bisa mengurangi diskriminasi gender atau melemahkan struktur patriarki dalam keluarga (Bélanger, 2002). Kontrasepsi lebih banyak digunakan oleh wanita yang telah memiliki anak laki-laki. Pemilihan jenis kelamin anak pada saat kehamilan dengan menggunakan teknologi kesehatan efektif bagi wanita yang ingin membatasi 
kelahiran sekaligus memastikan kelahiran anak laki-laki (Guilmoto, 2012).

Program kependudukan dan KB di Indonesia sejak lama telah mengampanyekan bahwa anak laki-laki dan perempuan memiliki nilai yang sama. Perbedaannya adalah pada peran masingmasing dalam keluarga. Kampanye tersebut dianggap cukup berhasil memberikan pemahaman kepada masyarakat sehingga berdampak pada penurunan angka fertilitas di Indonesia.

Indonesia dipandang sebagai salah satu negara di Asia yang bebas dari diskriminasi gender. Preferensi jenis kelamin anak tertentu dianggap tidak lagi berpengaruh dalam menentukan jumlah anak yang diinginkan (Guilmoto, 2015). Namun, sebagian besar pasangan suami istri tetap menginginkan sejumlah anak dengan komposisi jenis kelamin yang lengkap, lakilaki dan perempuan. Penelitian ini bertujuan untuk mempelajari keterkaitan antara jumlah dan komposisi jenis kelamin anak dalam keluarga, pemakaian kontrasepsi, dan keinginan memiliki anak lagi pada wanita di Indonesia.

\section{METODOLOGI}

Data yang digunakan dalam penelitian ini bersumber dari hasil Survei Demografi dan Kesehatan Indonesia (SDKI) tahun 2017. Unit analisis penelitian ini adalah wanita bertatus kawin umur 15-49 tahun yang telah memiliki minimal satu anak masih hidup. Kajian ini mengelompokkan wanita menurut jumlah dan komposisi jenis kelamin dari anak masih hidup yang dimilikinya. Responden wanita pada SDKI 2017 juga ditanya tentang kontrasepsi yang dipakai serta keinginan memiliki anak lagi. Variabel lain dalam penelitian ini seperti daerah tempat tinggal, tingkat pendidikan, status bekerja dan kuintil kekayaan digunakan untuk memberikan informasi mengenai latar belakang wanita.

Analisis deskriptif univariat dilakukan untuk menggambarkan kondisi wanita secara umum dengan menyajikan tabel persentase menurut variabel karakteristiknya. Selanjutnya, analisis bivariat dilakukan dengan menyajikan tabulasi persentase wanita yang tidak memakai kontra- sepsi dan persentase wanita yang menginginkan anak lagi. Tabulasi ini berdasarkan jumlah anak masih hidup yang dimiliki dan komposisi jenis kelaminnya.

Analisis multivariat dengan regresi logistik biner digunakan untuk mengestimasi rasio kecenderungan status tidak pakai kontrasepsi dan keinginan memiliki anak lagi menurut jumlah dan komposisi anak masih hidup. Oleh karena itu, variabel terikat pada analisis multivariat dalam penelitian ini adalah pemakaian kontrasepsi dan keinginan memiliki anak lagi dengan masingmasing variabel terdiri dari dua kategori. Model regresi logistik yang dihasilkan disusun terpisah berdasarkan jumlah anak masih hidup yang dimiliki, sehingga jumlah sampel yang digunakan berbeda untuk setiap model regresi yang terbentuk. Kategori referensi yang digunakan untuk variabel jumlah dan komposisi jenis kelamin anak disesuaikan dengan tujuan untuk memudahkan analisis. Variabel karakteristik lainnya seperti daerah tempat tinggal, tingkat pendidikan, status bekerja dan kuintil kekayaan diperlakukan sebagai variabel kontrol dan tidak ditampilkan dalam model regresi.

\section{HASIL DAN PEMBAHASAN}

Berdasarkan jumlah anak masih hidup yang dimiliki, wanita dengan dua anak masih hidup memiliki proporsi paling besar. Proporsi paling besar adalah wanita yang telah memiliki dua anak, laki-laki dan perempuan. Wanita yang memiliki empat anak masih hidup atau lebih memiliki proporsi paling kecil yaitu sekitar $12 \%$ (Tabel 1).

Sekitar tiga dari sepuluh wanita (32\%) mengatakan bahwa mereka tidak memakai kontrasepsi saat survei dilakukan. Selanjutnya, lebih dari $41 \%$ wanita menyatakan bahwa mereka masih menginginkan anak lagi. Proporsi wanita yang tinggal di perdesaan lebih besar dibandingkan dengan wanita di perkotaan. Sebagian besar wanita memiliki tingkat pendidikan menengah (SMP dan SMA) dan menyatakan bahwa mereka bekerja (52\% dan 56\%). Berdasarkan kuintil kekayaan, sekitar $42 \%$ wanita berasal dari rumah tangga pada kuintil kekayaan menengah atas dan teratas. 
Tabel 1. Distribusi persentase wanita status kawin 15-49 tahun dengan minimal satu orang anak masih hidup berdasarkan karakteristik, SDKI 2017

\begin{tabular}{|c|c|c|}
\hline & Karakteristik & $\begin{array}{l}\text { Persentase } \\
(\mathrm{N}=32.980)\end{array}$ \\
\hline \multicolumn{3}{|c|}{$\begin{array}{l}\text { Jumlah anak masih hidup/komposisi } \\
\text { jenis kelamin anak }\end{array}$} \\
\hline \multirow[t]{2}{*}{1 anak } & : 1 laki-laki & 14,5 \\
\hline & 1 perempuan & 14,1 \\
\hline \multirow[t]{3}{*}{2 anak } & : 2 laki-laki & 9,8 \\
\hline & 1 laki-laki, 1 perempuan & 19,9 \\
\hline & 2 perempuan & 9,3 \\
\hline \multirow[t]{4}{*}{3 anak } & : 3 laki-laki & 2,7 \\
\hline & 2 laki-laki, 1 perempuan & 7,9 \\
\hline & 1 laki-laki, 2 perempuan & 7,4 \\
\hline & 3 perempuan & 2,2 \\
\hline \multirow[t]{5}{*}{$\geq 4$ anak } & : semua laki-laki & 0,7 \\
\hline & laki-laki > perempuan & 4,2 \\
\hline & laki-laki $=$ perempuan & 3,1 \\
\hline & laki-laki $<$ perempuan & 3,7 \\
\hline & semua perempuan & 0,5 \\
\hline \multicolumn{3}{|c|}{ Status pakai kontrasepsi } \\
\hline & Pakai kontrasepsi & 68,4 \\
\hline \multirow{2}{*}{\multicolumn{3}{|c|}{ Status ingin anak lagi }} \\
\hline & & \\
\hline & Tidak ingin anak lagi & 58,6 \\
\hline & Ingin anak lagi & 41,4 \\
\hline \multicolumn{3}{|c|}{ Daerah tempat tinggal } \\
\hline & Perkotaan & 48,2 \\
\hline & Perdesaan & 51,8 \\
\hline \multicolumn{3}{|c|}{ Tingkat pendidikan } \\
\hline & Tidak sekolah & 1,8 \\
\hline & SD & 35,0 \\
\hline & SMP-SMA & 51,8 \\
\hline & Perguruan tinggi & 11,4 \\
\hline \multicolumn{3}{|c|}{ Status bekerja } \\
\hline & Bekerja & 55,8 \\
\hline & Tidak bekerja & 44,2 \\
\hline \multicolumn{3}{|c|}{ Kuintil kekayaan } \\
\hline & Terbawah & 17,6 \\
\hline & Menengah bawah & 20,0 \\
\hline & Menengah & 20,7 \\
\hline & Menengah atas & 21,1 \\
\hline & Teratas & 20,5 \\
\hline & Total & 100,0 \\
\hline
\end{tabular}

\section{Pemakaian Kontrasepsi}

Tabel 2 menyajikan persentase wanita status kawin 15-49 tahun yang memiliki minimal satu anak masih hidup berdasarkan status tidak pakai kontrasepsi. Sekitar 32\% wanita mengatakan bahwa mereka tidak memakai kontrasepsi pada saat survei dilaksanakan. Persentase tidak memakai kontrasepsi paling tinggi adalah pada mereka yang hanya memiliki satu anak lakilaki (44\%). Persentasenya hanya berbeda sedikit (sekitar 1\%) dibanding wanita yang memiliki satu anak perempuan.

Tabel 2. Persentase wanita status kawin 15-49 tahun dengan minimal satu orang anak masih hidup berdasarkan status tidak pakai kontrasepsi dan keinginan memiliki anak lagi, SDKI 2017

\begin{tabular}{|c|c|c|}
\hline $\begin{array}{l}\text { Jumlah anak masih hidup } \\
\text { dan komposisi jenis kelamin } \\
\text { anak }\end{array}$ & $\begin{array}{c}\% \\
\text { tidak } \\
\text { pakai } \\
\text { kontra- } \\
\text { sepsi }\end{array}$ & $\begin{array}{c}\% \\
\text { ingin } \\
\text { anak } \\
\text { lagi }\end{array}$ \\
\hline 1 anak : 1 laki-laki & 44,1 & 84,6 \\
\hline 1 perempuan & 43,3 & 82,1 \\
\hline 2 anak : 2 laki-laki & 27,9 & 41,2 \\
\hline $\begin{array}{l}1 \text { laki-laki, } \\
1 \text { perempuan }\end{array}$ & 23,9 & 28,3 \\
\hline 2 perempuan & 24,8 & 37,5 \\
\hline 3 anak : 3 laki-laki & 27,8 & 24,3 \\
\hline $\begin{array}{l}2 \text { laki-laki, } \\
1 \text { perempuan }\end{array}$ & 24,8 & 12,6 \\
\hline $\begin{array}{l}1 \text { laki-laki, } \\
2 \text { perempuan }\end{array}$ & 25,9 & 15,3 \\
\hline 3 perempuan & 25,4 & 22,3 \\
\hline $\begin{array}{l}\geq 4 \quad: \text { semua laki-laki } \\
\text { anak }\end{array}$ & 34,4 & 19,1 \\
\hline laki-laki $>$ perempuan & 34,7 & 7,2 \\
\hline laki-laki $=$ perempuan & 30,2 & 8,9 \\
\hline laki-laki $<$ perempuan & 34,3 & 7,7 \\
\hline semua perempuan & 35,6 & 16,7 \\
\hline Total & 31,6 & 41,4 \\
\hline
\end{tabular}

Tabel 2 mengindikasikan bahwa pasangan suami istri yang baru memiliki satu orang anak masih hidup masih berkeinginan untuk menambah jumlah anak. Salah satu cara yang dilakukan untuk mewujudkan keinginan tersebut adalah dengan tidak memakai alat kontrasepsi. Pemakaian kontrasepsi pada pasangan yang baru memiliki satu anak kemungkinan lebih ditujukan untuk mengatur jarak antar kehamilan. Keinginan dan persetujuan pasangan suami istri untuk mengikuti program KB dengan memakai kontrasepsi sangat tergantung pada preferensi mereka terhadap fertilitas (Borges dkk., 2018). Hasil SDKI tahun 
2017 menunjukkan bahwa rata-rata jumlah anak ideal untuk wanita 15-49 tahun di Indonesia adalah 2,7 anak (BKKBN dkk., 2018).

Di antara wanita yang telah memiliki dua anak masih hidup, persentase yang tidak memakai kontrasepsi paling rendah pada mereka yang memiliki anak dengan jenis kelamin lengkap, lakilaki dan perempuan (24\%). Persentase tertinggi adalah wanita dengan kedua anaknya berjenis kelamin laki-laki (28\%). Pola yang sama juga terlihat pada wanita yang telah memiliki tiga anak masih hidup. Persentase paling tinggi yang tidak memakai kontrasepsi adalah wanita yang ketiga anaknya berjenis kelamin laki-laki (28\%). Hal ini menunjukkan bahwa kecenderungan untuk memakai kontrasepsi di antara wanita dengan dua atau tiga anak adalah pada mereka yang telah memiliki anak dengan jenis kelamin lengkap laki-laki dan perempuan.

Pola pemakaian kontrasepsi pada pasangan suami istri bervariasi, tergantung pada jumlah anak laki-laki dan perempuan yang sudah dimiliki. Berbagai penelitian menunjukkan bahwa pada negara dengan preferensi anak lakilaki lebih tinggi, proporsi wanita yang memakai kontrasepsi lebih tinggi setelah kelahiran anak laki-laki dibandingkan kelahiran anak perempuan (Bongaarts, 2013; Retherford \& Roy, 2003) Hasil penelitian di Bangladesh menunjukkan bahwa persentase wanita dengan dua atau tiga anak yang menggunakan kontrasepsi tertinggi adalah pada mereka yang telah memiliki paling tidak satu anak laki-laki (Jayaraman dkk., 2009). Hal tersebut disebabkan budaya patrilineal pada negara-negara di Asia Selatan. Anak laki-laki dianggap lebih berharga dan lebih diinginkan dalam keluarga dibandingkan dengan anak perempuan. Penelitian lainnya menyebutkan bahwa pada negara dengan preferensi anak laki-laki, proporsi wanita yang memakai kontrasepsi lebih tinggi setelah kelahiran anak laki-laki daripada setelah kelahiran anak perempuan (Retherford \& Roy, 2003).

Secara umum, persentase wanita dengan empat anak masih hidup atau lebih yang tidak memakai kontrasepsi sebesar 32\%. Persentase tertinggi adalah pada wanita yang seluruh anaknya berjenis kelamin perempuan $(36 \%)$ dan persentase terendah adalah pada wanita yang jumlah anak laki-lakinya sama dengan jumlah anak perempuannya (30\%).

Pola yang sama juga dapat dilihat berdasarkan wilayah tempat tinggal (Lampiran 1). Persentase wanita yang tidak memakai kontrasepsi di perkotaan maupun di perdesaan selalu lebih tinggi pada mereka yang memiliki beberapa anak dengan jenis kelamin yang sama dibandingkan mereka yang telah memiliki beberapa anak dengan jenis kelamin berbeda. Sebagai contoh, persentase wanita tidak pakai kontrasepsi dengan dua anak berjenis kelamin laki-laki di perkotaan maupun di perdesaan selalu lebih tinggi (masing-masing $29 \%$ dan 27\%) dibandingkan dengan mereka yang memiliki dua anak dengan jenis kelamin berbeda (masing-masing 25\% dan 23\%). Dengan kata lain, wanita di perkotaan dan pedesaan yang memiliki lebih dari satu anak masih hidup dengan satu jenis kelamin tertentu memiliki kecenderungan untuk tidak memakai kontrasepsi.

Lampiran 2 menyajikan persentase wanita status kawin 15-49 tahun dengan minimal satu orang anak masih hidup menurut status tidak pakai KB dan keinginan memiliki anak lagi berdasarkan tingkat pendidikan wanita. Persentase wanita tidak ber-KB yang berpendidikan sekolah dasar atau lebih yang memiliki minimal dua orang anak masih hidup berjenis kelamin sama selalu lebih tinggi dibandingkan dengan mereka yang memiliki beberapa anak dengan jenis kelamin lengkap, laki-laki dan perempuan. Namun, pola yang berbeda terlihat pada wanita yang tidak pernah sekolah yang menunjukkan persentase lebih besar.

\section{Keinginan Memiliki Anak Lagi}

Tabel 2 menyajikan persentase wanita berusia 15-49 tahun dengan status kawin berdasarkan keinginan memiliki anak lagi. Secara umum, sekitar 41\% wanita usia 15-49 tahun di Indonesia masih menginginkan anak lagi. Persentase wanita yang menginginkan anak lagi menurun seiring dengan banyaknya jumlah anak masih hidup yang dimiliki. Namun, jenis kelamin anak ternyata memiliki pengaruh terhadap keinginan mereka untuk memiliki anak lagi atau tidak. Sebagai contoh, persentase wanita dengan satu anak laki-laki 
yang ingin anak lagi adalah $85 \%$ dibandingkan dengan wanita yang telah memiliki tiga orang anak perempuan yaitu sekitar $22 \%$.

Selain wanita dengan satu orang anak masih hidup, persentase keinginan memiliki anak lagi selalu lebih kecil pada wanita yang telah memiliki anak lengkap, laki-laki dan perempuan dibanding dengan wanita yang hanya memiliki anak laki-laki saja atau anak perempuan saja. Sebagai contoh, proporsi wanita yang menginginkan anak lagi lebih tinggi pada mereka yang memiliki tiga anak laki-laki atau tiga anak perempuan (masingmasing sebesar $24 \%$ dan $22 \%$ ) dibandingkan dengan mereka yang memiliki tiga anak berjenis kelamin lengkap laki-laki dan perempuan (masing-masing sebesar 13\% dan 15\%.

Di antara wanita yang memiliki empat anak atau lebih, persentase tertinggi yang ingin memiliki anak lagi adalah pada mereka yang sama sekali belum memiliki anak perempuan, yaitu sekitar 19\%. Selanjutnya, sekitar $17 \%$ wanita dengan empat anak perempuan masih menginginkan anak lagi. Persentase wanita ingin memiliki anak lagi lebih kecil pada mereka yang telah memiliki anak laki-laki dan anak perempuan. Hal ini sejalan dengan hasil penelitian di Malawi yang menyatakan bahwa proporsi tertinggi wanita yang menginginkan anak lagi adalah pada mereka yang telah memiliki beberapa anak dengan jenis kelamin yang sama (Adebowale \& Palamuleni, 2015) GP and Living Children's Sex Composition (LCSC).

Pada Lampiran 1 terlihat bahwa persentase wanita yang ingin anak lagi di perkotaan maupun di perdesaan selalu lebih tinggi pada mereka yang telah memiliki minimal dua anak dengan jenis kelamin yang sama dibandingkan dengan wanita yang telah memiliki beberapa anak dengan jenis kelamin laki-laki dan perempuan. Pola yang sama juga terlihat berdasarkan tingkat pendidikan wanita (Lampiran 2).

\section{Pengaruh Jumlah dan Komposisi Jenis Kelamin Anak terhadap Pemakaian Kontrasepsi}

Analisis multivariat dilakukan dengan menyusun model regresi logistik biner dengan variabel terikat pemakaian kontrasepsi dan keinginan memiliki anak lagi. Variabel bebas selain jumlah dan komposisi jenis kelamin anak diperlakukan sebagai variabel kontrol dan tidak ditampilkan dalam model regresi.

Tabel 3 menyajikan rasio kecenderungan pengaruh dari jumlah dan komposisi anak masih hidup yang dimiliki terhadap status tidak pakai kontrasepsi. Secara umum pada setiap kelompok wanita yang telah memiliki dua anak masih hidup atau lebih, mereka yang memiliki anak laki-laki saja atau anak perempuan saja punya kecenderungan lebih tinggi untuk tidak memakai kontrasepsi.

Pola yang sama juga terlihat pada kelompok wanita yang telah memiliki tiga dan empat orang anak atau lebih. Kecenderungan wanita tidak memakai kontrasepsi lebih tinggi adalah pada mereka yang hanya memiliki anak laki-laki saja atau anak perempuan saja.

Tabel 3. Rasio kecenderungan (odds ratio) pengaruh jumlah dan komposisi jenis kelamin anak terhadap status tidak pakai kontrasepsi berdasarkan regresi logistik biner, SDKI 2017

\begin{tabular}{|c|c|c|c|}
\hline \multicolumn{2}{|c|}{$\begin{array}{l}\text { Jumlah anak masih hidup/ } \\
\text { komposisi jenis kelamin } \\
\text { anak }\end{array}$} & \multirow{2}{*}{$\begin{array}{l}\text { OR } \\
1,00\end{array}$} & \multirow[t]{2}{*}{ SK 95\% } \\
\hline 1 anak & : 1 laki-laki & & \\
\hline$(\mathrm{N}=9.445)$ & 1 perempuan & 0,96 & $0,89-1,04$ \\
\hline \multirow{3}{*}{$\begin{array}{l}2 \text { anak } \\
(\mathrm{N}=12.883)\end{array}$} & : 2 laki-laki & $1,25^{* *}$ & $1,14-1,38$ \\
\hline & $\begin{array}{l}1 \text { laki-laki, } \\
1 \text { perempuan }\end{array}$ & 1,00 & \\
\hline & 2 perempuan & 1,07 & $0,96-1,18$ \\
\hline \multirow{4}{*}{$\begin{array}{l}3 \text { anak } \\
(\mathrm{N}=6.627)\end{array}$} & : 3 laki-laki & $1,18^{*}$ & $0,99-1,40$ \\
\hline & $\begin{array}{l}2 \text { laki-laki, } \\
1 \text { perempuan }\end{array}$ & 1,00 & \\
\hline & $\begin{array}{l}1 \text { laki-laki, } \\
2 \text { perempuan }\end{array}$ & 1,05 & $0,93-1,19$ \\
\hline & 3 perempuan & 1,04 & $0,86-1,27$ \\
\hline \multirow{6}{*}{$\begin{array}{l}\geq 4 \text { anak } \\
(\mathrm{N}=4.025)\end{array}$} & : semua laki-laki & $1,27^{*}$ & $0,94-1,73$ \\
\hline & $\begin{array}{l}\text { laki-laki > } \\
\text { perempuan }\end{array}$ & $1,19 * *$ & $1,00-1,43$ \\
\hline & $\begin{array}{l}\text { laki-laki = } \\
\text { perempuan }\end{array}$ & 1,00 & \\
\hline & laki-laki & $1,21 * *$ & $1,01-1,46$ \\
\hline & $<$ perempuan & & \\
\hline & $\begin{array}{l}\text { semua } \\
\text { perempuan }\end{array}$ & $1,33 *$ & $0,95-1,87$ \\
\hline
\end{tabular}


Temuan hasil penelitian ini sejalan dengan hasil kajian sebelumnya yang menyebutkan bahwa di antara wanita dengan dua anak, mereka yang memiliki dua anak perempuan memiliki kemungkinan yang lebih rendah untuk menggunakan kontrasepsi (Smith-Greenaway dkk., 2019). Selanjutnya, hasil penelitian kualitatif yang dilakukan di Jawa Tengah dan Sulawesi Tenggara menyebutkan bahwa derajat anak perempuan dan anak laki-laki sebenarnya sama saja. Setiap keluarga yang belum memiliki anak dengan jenis kelamin lengkap cenderung tidak memakai kontrasepsi, berkeinginan menambah anaknya dan berhenti setelah memperoleh enam orang anak. Alasan mereka berhenti menambah anak lebih karena masalah ekonomi (Nurjono, 2014). Hasil penelitian lainnya di Provinsi Nusa Tenggara Timur menunjukkan bahwa alasan rendahnya pemakaian kontrasepsi dan besarnya keinginan untuk memiliki anak lagi disebabkan oleh dominasi keputusan suami dan keluarga besarnya (Rahmadewi \& Asih, 2011).

\section{Pengaruh Jumlah dan Komposisi Jenis Kelamin Anak terhadap Keinginan Memiliki Anak Lagi}

Tabel 4 menyajikan hasil analisis regresi logistik berupa rasio kecenderungan wanita yang menginginkan anak lagi. Jumlah dan komposisi jenis kelamin anak yang dimiliki mempunyai hubungan signifikan dengan keinginan wanita untuk memiliki anak lagi.

Secara umum terlihat bahwa wanita dengan dua anak masih hidup atau lebih yang semuanya laki-laki atau perempuan memiliki kecenderungan lebih tinggi untuk ingin memiliki anak lagi dibandingkan dengan wanita yang telah memiliki anak laki-laki dan perempuan. Sebagai contoh, pada kelompok wanita yang memiliki tiga anak dan ketiganya adalah laki-laki memiliki kecenderungan tertinggi untuk menginginkan anak lagi $(\mathrm{OR}=2,26)$ dibandingkan dengan mereka yang telah memiliki anak laki-laki dan perempuan.

Berdasarkan hasil analisis regresi logistik pada masing-masing kelompok wanita menurut jumlah anak diketahui bahwa rasio kecenderungan tertinggi ingin anak lagi adalah pada wanita de-
Tabel 4. Rasio kecenderungan (odds ratio) pengaruh jumlah dan komposisi jenis kelamin anak terhadap keinginan memiliki anak lagi berdasarkan regresi logistik biner, SDKI 2017

\begin{tabular}{|c|c|c|c|}
\hline \multicolumn{2}{|c|}{$\begin{array}{l}\text { Jumlah anak masih hidup/ } \\
\text { komposisi jenis kelamin } \\
\text { anak }\end{array}$} & \multirow{2}{*}{$\begin{array}{l}\text { OR } \\
1,00\end{array}$} & \multirow[t]{2}{*}{ SK 95\% } \\
\hline 1 anak & : 1 laki-laki & & \\
\hline$(\mathrm{N}=9.445)$ & 1 perempuan & $0,85^{* *}$ & $0,76-0,95$ \\
\hline \multirow{3}{*}{$\begin{array}{l}2 \text { anak } \\
(\mathrm{N}=12.883)\end{array}$} & : 2 laki-laki & $1,79 * *$ & $1,64-1,97$ \\
\hline & $\begin{array}{l}1 \text { laki-laki, } \\
1 \text { perempuan }\end{array}$ & 1,00 & \\
\hline & 2 perempuan & $1,57 * *$ & $1,43-1,71$ \\
\hline \multirow{4}{*}{$\begin{array}{l}3 \text { anak } \\
(\mathrm{N}=6.627)\end{array}$} & : 3 laki-laki & $2,26 * *$ & $1,86-2,76$ \\
\hline & $\begin{array}{l}2 \text { laki-laki, } \\
1 \text { perempuan }\end{array}$ & 1,00 & \\
\hline & $\begin{array}{l}1 \text { laki-laki, } \\
2 \text { perempuan }\end{array}$ & $1,25^{* *}$ & $1,06-1,47$ \\
\hline & 3 perempuan & $2,04 * *$ & $1,64-2,53$ \\
\hline \multirow{5}{*}{$\begin{array}{l}\geq 4 \text { anak } \\
(\mathrm{N}=4.025)\end{array}$} & : semua laki-laki & $2,53 * *$ & $1,69-3,78$ \\
\hline & $\begin{array}{l}\text { laki-laki > } \\
\text { perempuan }\end{array}$ & $0,76^{*}$ & $0,56-1,03$ \\
\hline & $\begin{array}{l}\text { laki-laki = } \\
\text { perempuan }\end{array}$ & 1,00 & \\
\hline & $\begin{array}{l}\text { laki-laki } \\
<\text { perempuan }\end{array}$ & 0,80 & $0,59-1,09$ \\
\hline & $\begin{array}{l}\text { semua } \\
\text { perempuan }\end{array}$ & $2,33 * *$ & $1,48-3,67$ \\
\hline
\end{tabular}

ngan empat anak atau lebih dan semua anaknya adalah laki-laki atau perempuan (masing-masing $\mathrm{OR}=2,53$ dan $\mathrm{OR}=2,33$ ). Hasil ini membuktikan bahwa sebagian besar wanita di Indonesia tetap menginginkan anak laki-laki maupun perempuan ada dalam keluarga mereka. Dengan demikian, kecenderungan ingin memiliki anak lagi akan tetap tinggi pada mereka yang hanya memiliki anak laki-laki atau anak perempuan saja.

Hasil analisis ini sejalan dengan penelitian kualitatif tentang jumlah anak ideal dan jenis kelamin anak yang diinginkan remaja wanita. Sebagian besar menyatakan bahwa ketika sudah berkeluarga, mereka ingin memiliki anak laki-laki dan anak perempuan. Apabila setelah memiliki dua anak namun keduanya laki-laki atau keduanya perempuan, sebagian besar remaja wanita berkeinginan untuk menambah anak lagi (Nurjono, 2014). Meskipun telah memiliki banyak anak, keinginan memiliki anak lagi pada beberapa 
negara di Asia juga disebabkan oleh preferensi orang tua terhadap jenis kelamin anak tertentu dalam keluarga (Abassi dkk., 2018; Leone dkk., 2003).

Hasil penelitian di Korea menunjukkan bahwa preferensi anak laki-laki menurun signifikan tetapi masih tetap mempengaruhi wanita untuk menginginkan anak lagi. Wanita dengan dua anak perempuan lebih mungkin untuk menginginkan anak lagi dibandingkan wanita dengan dua anak laki-laki. Intensi fertilitas juga berbeda antara wanita dengan dua anak perempuan dan wanita yang telah memiliki satu anak laki-laki dan satu anak perempuan (Yoo dkk., 2017). Sebaliknya, hasil penelitian di Swedia menunjukkan bahwa pola preferensi untuk anak perempuan menguat dibandingkan anak laki-laki. Pada masyarakat yang memberikan peluang bagi kaum perempuan untuk mengembangkan potensinya, anak perempuan memiliki nilai lebih berharga bagi orang tua (Miranda dkk., 2018)

\section{KESIMPULAN}

Hasil penelitian ini menunjukkan bahwa preferensi orang tua untuk memiliki anak dengan jenis kelamin baik laki-laki dan perempuan dalam keluarga mereka memiliki pengaruh terhadap fertilitas dan pemakaian kontrasepsi di Indonesia. Kontribusi hasil penelitian ini menjelaskan bahwa praktek KB dan keinginan anak lagi berbeda menurut jumlah dan komposisi jenis kelamin anak yang telah dimiliki. Secara umum, wanita dengan dua anak masih hidup atau lebih namun semua anaknya berjenis kelamin tertentu cenderung tidak menggunakan kontrasepsi. Selanjutnya, keinginan untuk memiliki anak lagi juga lebih tinggi pada wanita yang hanya memiliki anak laki-laki atau perempuan.

Hasil penelitian ini menjadi salah satu bukti empiris yang tidak sejalan dengan kampanye program KB selama ini yaitu "anak laki-laki dan perempuan sama saja." Meskipun preferensi terhadap jenis kelamin anak tertentu sudah tidak terlihat, sebagian besar pasangan suami istri di Indonesia masih tetap menginginkan kehadiran anak laki-laki maupun anak perempuan dalam keluarga mereka. Hal tersebut berkaitan dengan perbedaan tugas serta peran anak laki-laki dan perempuan yang dalam keluarga. Oleh karena itu, perlu direkayasa kembali konsep yang efektif untuk sosialisasi yang tepat sebagai upaya mengontrol tingkat fertilitas di Indonesia.

\section{UCAPAN TERIMA KASIH}

Penulis mengucapkan terima kasih kepada Kepala Puslitbang Kependudukan BKKBN yang telah memberikan bantuan serta kesempatan untuk melakukan kajian ini.

\section{DAFTAR PUSTAKA}

Abassi, Z., Keshavarz, Z., Abbasi-Shavazi, M. J., Ebadi, A., \& Esmaily, H. (2018). Factors affecting women's sex preference in multiethnic society in North Khorasan Province, Iran. Electronic Physician, 10(7), 7063-7070. https://doi.org/10.19082/7063

Adebowale, S. A., \& Palamuleni, M. E. (2015). Influence of gender preference and sex composition of surviving children on childbearing intention among high fertility married women in stable union in Malawi. African Health Sciences, 15(1), 150-160. https://doi.org/10.4314/ahs. v15i1.21

Arnold, F. (2001). Son preference in South Asia. Dalam Z.A. Sathar \& J.F. Phillips (Ed.), Fertility transition in South Asia (281-299). https://econpapers.repec.org/ RePEc:oxp:obooks:9780199241859

Bélanger, D. (2002). Son preference in a rural village in North Vietnam. Studies in Family Planning, 33, 321-334. https://doi.org/10.1111/j.17284465.2002.00321.x

BKKBN, BPS, Kementerian Kesehatan, \& ICF. (2018). Indonesia demographic and health survey 2017. Jakarta, Indonesia.

Bongaarts, J. (2013). The implementation of preferences for male offspring. Population and Development Review, 39(2), 185-208. https:// doi.org/10.1111/j.1728-4457.2013.00588.x

Borges, A. L. V., Dos Santos, O. A., \& Fujimori, E. (2018). Concordance between intention to use and current use of contraceptives among sixmonth postpartum women in Brazil: The role of unplanned pregnancy. Midwifery, 56, 94-101. https://doi.org/10.1016/j.midw.2017.10.015

Bulatao, R.A., \& Lee, R. (1983). Determinant of fertility in developing countries: Fertility regulation and institutional influences. Academic Press. 
Easterlin, R. A. (1983). Modernization and fertility: A critical essay. Dalam R.A. Bulatao \& R. Lee (Ed.), Determinant of fertility in developing countries: Fertility regulation and institutional influences (562-586). Academic Press.

Fuse, K. (2013). Daughter preference in Japan: A reflection of gender role attitudes? Demographic Research, 28, 1021-1052. https://doi. org/10.4054/DemRes.2013.28.36

Guilmoto, C. Z. (2012). Son preference, sex selection, and kinship in Vietnam. Population and Development Review, 3(1), 31-54. http://www. jstor.org/stable/41857356\%0A

Guilmoto, C. Z. (2015). Mapping the diversity of gender preferences and sex imbalances in Indonesia in 2010. Population Studies, 69(3), 299-315. https://doi.org/10.1080/00324728.2 015.1091603

Hastono, S. P. (2009). Peran faktor komposisional dan faktor kontekstual terhadap jumlah anak yang diinginkan di indonesia: Permodelan dengan analisis multilevel-Analisis lanjut SDKI 2007. Penerbit KB dan Kesehatan Reproduksi, BKKBN.

Jayaraman, A., Mishra, V., \& Arnold, F. (2009). The relationship of family size and composition to fertility desires, contraceptive adoption and method choice in South Asia. International Family Planning Perspectives, 35(1), 29-38. https://doi.org/10.1363/3502909

Johansson, L., Sundström, G., \& Hassing, L. B. (2003). State provision down, offspring's up: The reverse substitution of old-age care in Sweden. Ageing and Society, 23(3), 269-280. https://doi.org/10.1017/S0144686X02001071

Leone, T., Matthews, Z., \& Dalla Zuanna, G. (2003). Impact and determinants of gender preference for children in Nepal. International Family Planning Perspectives, 29(2), 69-75. http:// r4d.dfid.gov.uk/Output/185044/Default.aspx

Mahadevan, K. P. J. \& Reddy, D. A. N. (1986). Fertility and mortality theory, methodology and empirical issues. Sage Publications India.
Margolis, R., \& Myrskyla, M. (2016). Children's sex and the happiness of parents. European Journal of Population, 32(3), 403-420. https://doi. org/10.1007/s10680-016-9387-z

Miranda, V., Dahlberg, J., \& Andersson, G. (2018). Parents' preferences for sex of children in Sweden: Attitudes and outcomes. Population Research and Policy Review, 37(3), 443-459. https://doi.org/10.1007/s11113-018-9462-8

Nurjono, D. A. (2014). Pandangan masyarakat tentang nilai anak di Provinsi Jawa Tengah dan Sulawesi Tenggara. Puslitbang Kependudukan BKKBN.

Rahmadewi, R., \& Asih, L. (2011). Tingkat fertilitas di Provinsi Nusa Tenggara Timur dan Yogyakarta. Kesmas: National Public Health Journal, 6(3), 117. https://doi.org/10.21109/kesmas.v6i3.102

Retherford, R. D., \& Roy, T. K. (2003). Factors affecting sex-selective abortion in India. NFHS Bulletin, 21. http://hdl.handle.net/10125/3461

Sandström, G., \& Vikström, L. (2015). Sex preference for children in German villages during the fertility transition. Population Studies, 69(1), 57-71. https://doi.org/10.1080/00324728.201 4.994667

Smith-Greenaway, E., Weitzman, A., \& Chilungo, A. (2019). Child sex composition, parental sex preferences, and marital outcomes: Evidence from a matrilineal context. Journal of Marriage and Family, 81(5), 1126-1143. https://doi. org/10.1111/jomf.12591

Wirawan I.B. (2007). Status wanita dalam perspektif kajian studi kependudukan. Masyarakat, Kebudayaan dan Politik, 20(3), 208-219. http://journal.unair.ac.id/download-fullpapersLepasan\%20Naskah\%205\%20(208-219).pdf

Yoo, S. H., Hayford, S. R., \& Agadjanian, V. (2017). Old habits die hard? Lingering son preference in an era of normalizing sex ratios at birth in South Korea. Population Research and Policy Review, 36(1), 25-54. https://doi.org/10.1007/ s11113-016-9405-1 
Lampiran 1. Persentase wanita status kawin usia 15-49 tahun dengan minimal 1 anak masih hidup menurut status tidak pakai KB dan keinginan memiliki anak lagi berdasarkan wilayah tempat tinggal, SDKI 2017

\begin{tabular}{|c|c|c|c|c|c|}
\hline \multirow{2}{*}{\multicolumn{2}{|c|}{$\begin{array}{l}\text { Jumlah anak masih hidup/ } \\
\text { komposisi jenis kelamin anak }\end{array}$}} & \multicolumn{2}{|c|}{ \% tidak pakai kontrasepsi } & \multicolumn{2}{|c|}{$\%$ ingin anak lagi } \\
\hline & & Perkotaan & Perdesaan & Perkotaan & Perdesaan \\
\hline \multirow[t]{2}{*}{1 anak } & : 1 laki-laki & 48,1 & 40,5 & 82,7 & 86,3 \\
\hline & 1 perempuan & 46,3 & 40,7 & 81,8 & 82,4 \\
\hline \multirow[t]{3}{*}{2 anak } & : 2 laki-laki & 28,6 & 27,4 & 37,0 & 45,2 \\
\hline & 1 laki-laki, 1 perempuan & 24,8 & 22,9 & 25,8 & 30,8 \\
\hline & 2 perempuan & 26,5 & 23,2 & 35,7 & 39,1 \\
\hline \multirow[t]{4}{*}{3 anak } & : 3 laki-laki & 25,2 & 30,7 & 18,8 & 30,0 \\
\hline & 2 laki-laki, 1 perempuan & 23,7 & 25,8 & 10,1 & 15,0 \\
\hline & 1 laki-laki, 2 perempuan & 22,8 & 28,8 & 10,9 & 19,7 \\
\hline & 3 perempuan & 21,9 & 29,1 & 17,0 & 28,2 \\
\hline \multirow[t]{5}{*}{$\geq 4$ anak } & : semua laki-laki & 28,4 & 39,7 & 13,8 & 23,8 \\
\hline & laki-laki > perempuan & 31,4 & 36,8 & 6,5 & 7,6 \\
\hline & laki-laki = perempuan & 27,6 & 32,2 & 6,3 & 10,9 \\
\hline & laki-laki $<$ perempuan & 31,0 & 36,5 & 4,0 & 10,2 \\
\hline & semua perempuan & 28,6 & 43,9 & 10,2 & 25,3 \\
\hline Total & & 31,9 & 31,3 & 38,8 & 43,7 \\
\hline
\end{tabular}

Lampiran 2. Persentase wanita status kawin usia 15-49 tahun dengan minimal 1 anak masih hidup menurut status tidak pakai KB dan keinginan memiliki anak lagi berdasarkan tingkat pendidikan wanita, SDKI 2017

\begin{tabular}{|c|c|c|c|c|c|c|c|c|c|}
\hline \multirow{2}{*}{\multicolumn{2}{|c|}{$\begin{array}{l}\text { Jumlah anak masih hidup/ } \\
\text { komposisi jenis kelamin anak }\end{array}$}} & \multicolumn{4}{|c|}{$\%$ tidak pakai kontrasepsi } & \multicolumn{4}{|c|}{$\%$ ingin anak lagi } \\
\hline & & \multirow{2}{*}{\begin{tabular}{|c|}
$\begin{array}{r}\text { Tidak } \\
\text { sekolah }\end{array}$ \\
71,5 \\
\end{tabular}} & \multirow{2}{*}{$\begin{array}{c}\begin{array}{c}\text { Sekolah } \\
\text { Dasar }\end{array} \\
45,2\end{array}$} & \multirow{2}{*}{$\begin{array}{c}\text { SMP- } \\
\text { SMA } \\
41,7\end{array}$} & \multirow{2}{*}{$\begin{array}{l}\mathbf{P T} \\
50,9\end{array}$} & \multirow{2}{*}{$\begin{array}{c}\begin{array}{c}\text { Tidak } \\
\text { sekolah }\end{array} \\
59,5\end{array}$} & \multirow{2}{*}{$\begin{array}{c}\text { Sekolah } \\
\text { Dasar }\end{array}$} & \multirow{2}{*}{$\begin{array}{c}\begin{array}{c}\text { SMP- } \\
\text { SMA }\end{array} \\
87,0\end{array}$} & \multirow{2}{*}{$\begin{array}{c}\text { PT } \\
90,3\end{array}$} \\
\hline 1 anak & : 1 laki-laki & & & & & & & & \\
\hline & 1 perempuan & 66,7 & 42,9 & 41,4 & 50,6 & 53,9 & 74,1 & 84,7 & 87,7 \\
\hline \multirow[t]{3}{*}{2 anak } & : 2 laki-laki & 54,4 & 29,5 & 25,9 & 29,4 & 43,3 & 39,1 & 41,4 & 45,4 \\
\hline & 1 laki-laki, 1 perempuan & 60,6 & 24,8 & 22,4 & 23,6 & 26,5 & 27,1 & 27,5 & 34,9 \\
\hline & 2 perempuan & 49,6 & 23,2 & 24,7 & 27,8 & 39,2 & 28,9 & 40,8 & 47,9 \\
\hline \multirow[t]{4}{*}{3 anak } & : 3 laki-laki & 28,5 & 27,5 & 28,7 & 24,7 & 22,1 & 25,3 & 21,9 & 33,0 \\
\hline & 2 laki-laki, 1 perempuan & 52,6 & 27,2 & 22,4 & 20,1 & 20,2 & 14,4 & 11,3 & 10,3 \\
\hline & 1 laki-laki, 2 perempuan & 57,0 & 28,7 & 22,1 & 24,4 & 19,3 & 16,0 & 14,6 & 15,0 \\
\hline & 3 perempuan & 47,1 & 26,8 & 23,9 & 22,8 & 12,4 & 23,1 & 21,5 & 25,8 \\
\hline \multirow[t]{5}{*}{$\geq 4$ anak } & : semua laki-laki & 58,3 & 35,6 & 32,9 & 23,3 & 7,9 & 23,6 & 17,1 & 1,2 \\
\hline & laki-laki > perempuan & 55,8 & 36,7 & 31,0 & 11,3 & 14,7 & 6,7 & 7,0 & 3,2 \\
\hline & laki-laki = perempuan & 71,0 & 29,1 & 28,3 & 17,6 & 12,3 & 9,0 & 8,3 & 9,5 \\
\hline & laki-laki < perempuan & 71,8 & 36,1 & 29,3 & 19,2 & 9,7 & 7,9 & 6,9 & 8,9 \\
\hline & semua perempuan & 60,9 & 46,6 & 21,2 & 29,8 & 9,7 & 22,8 & 12,2 & 10,3 \\
\hline Total & & 60,0 & 31,4 & 30,2 & 33,6 & 26,7 & 32,5 & 45,7 & 51,5 \\
\hline
\end{tabular}

